\title{
Perceptions of health professionals on social inclusion in a Psychosocial Care Center
}

\author{
Percepções de profissionais de saúde sobre inclusão social em um Centro de Atenção \\ Psicossocial
}

Dulcian Medeiros de Azevedo ${ }^{1}$, Glauber Weder dos Santos Silva², Francisco Arnoldo Nunes de Miranda², Mônica Silva de Bessa ${ }^{1}$, Suerda Lillian da Fonseca Lins ${ }^{2}$, João Evangelista da Costa ${ }^{3}$

\begin{abstract}
Objective: to understand the perceptions of the technical team about social inclusion in the Psychosocial Care Center. Methods: qualitative research, developed with 20 health professionals. A semi-structured interview technique and non-participant observation were used. Data analyzed through the descending hierarchical classification and content thematic analysis, processed in the Analyse Lexicale par Contexte d'un Ensemble de Segments de Texte software. Results: three categories emerged: Social inclusion, family participation in inclusion/ exclusion and income generation; Therapeutic activities: inclusion inside and outside the Psychosocial Care Center; and Challenges of inclusion: service management and professional training. Conclusion: prejudice or discrimination in this field, coupled with the difficulties of support of the management with service and stiffening of the work process with centrality in the psychiatric consultation, jeopardize attempts at rehabilitation and social inclusion of users and families.
\end{abstract}

Descriptors: Social Support; Mental Health Services; Psychiatric Nursing; Mental Health.

Objetivo: compreender as percepções de equipe técnica sobre inclusão social em um Centro de Atenção Psicossocial. Métodos: pesquisa qualitativa, desenvolvida com 20 profissionais de saúde. Utilizaram-se a técnica de entrevista semiestruturada e a observação não participante. Dados analisados por meio da classificação hierárquica descendente e análise temática de conteúdo, processados no software Analyse Lexicale par Contexte d'un Ensemble de Segments de Texte. Resultados: emergiram-se três categorias: Inclusão social: participação familiar na inclusão/exclusão e a geração de renda; Atividades terapêuticas: inclusão "dentro e fora" do Centro de Atenção Psicossocial; e Desafios da inclusão: gestão do serviço e capacitação profissional. Conclusão: o preconceito ou a discriminação neste campo, aliado às dificuldades de apoio da gestão com serviço e "engessamento" do processo de trabalho com centralidade na consulta psiquiátrica, prejudica as tentativas de reabilitação e inclusão social de usuários e famílias.

Descritores: Apoio Social; Serviços de Saúde Mental; Enfermagem Psiquiátrica; Saúde Mental.

\footnotetext{
${ }^{1}$ Universidade do Estado do Rio Grande do Norte. Caicó, RN, Brazil.

${ }^{2}$ Universidade Federal do Rio Grande do Norte. Natal, RN, Brazil.

${ }^{2}$ Hospital Universitário Onofre Lopes. Natal, RN, Brazil.

Corresponding author: Dulcian Medeiros de Azevedo

Universidade do Estado do Rio Grande do Norte, Campus Caicó, Av. Rio Branco, 725 - Bairro Paraíba. CEP: 593000-000. Caicó, RN, Brazil. E-mail: professordulcian@gmail.com
} 


\section{Introduction}

The Psychiatric Reform is a worldwide phenomenon that guides the re-signification of mental health care, aiming at overcoming the asylum model (hospital and closed) by network care with substitutive health services (community and open), supported by the paradigm of deinstitutionalization which strengthen social reintegration and coexistence in the territory ${ }^{(1)}$. The replacement network is responsible for the fight against social exclusion and autonomy of the sick person, with principles of reception and bonding, allowing shared decision-making between service users and their families ${ }^{(2)}$.

In the perspective of the National Mental Health Policy, under the aegis of the doctrinal principles of the Unified Health System, Psychosocial Care Centers are substitutive services that propose the development of social inclusion actions for people with mental disorders and/or users of psychoactive substances and families, producing interferences in everyday life and territory, with new discourses and practices, in accordance with the presuppositions of the Psychiatric Reform, aiming at deinstitutionalization and social inclusion ${ }^{(3)}$.

In this sense, substitute services must develop strategies for rehabilitation and reintegration that promote the protagonism of users, initiatives articulated with the resources of the territory, in the fields of work/solidarity economy, habilitation, education, culture and health.

Despite the premise of co-participation of users and caregivers as protagonists in mental health care planning, there are challenges in this process, which exist due to inconsistencies in the implementation of the service and finite resources, persistence in the continuity of ritualistic actions and professional resistance to the participation of the user, which prevents the collaborative involvement and substitutes it for unilateral decisions, reproducing the feeling of marginalization between service users and family members $^{(4)}$.
Historically, as a result of hospital-centered and segregating care with a negative effect on mental health care, the exclusion of users from community life is reinforced against stereotypes, labeling, prejudices and stigma, fueled by the false idea of hetero and self-aggressiveness as a trigger for dangerousness of the person with mental disorder or user of psychoactive substance. These, among others, reinforce exclusionary attitudes such as isolation from society, marginalization and emotional disruption ${ }^{(3)}$. Therefore, it is up to the health services to devise strategies to promote quality of life in different dimensions and at a social level, in addition to establishing plans for reinsertion of this user ${ }^{(5)}$.

Thus, when considering the presence of these substitutive services and the ongoing reformist movement, the question was: how are social inclusion activities carried out in a Psychosocial Care Center in a medium-sized municipality? What are the challenges in the development of these activities, according to the health technical team of the Psychosocial Care Center?

In this sense, the objective was to understand the perceptions of the technical team about social inclusion in the Psychosocial Care Center.

\section{Methods}

Qualitative research, developed with professionals of the technical team of the Psychosocial Care Center III, in the municipality of Caicó, Rio Grande do Norte, Brazil, from July to August, 2016.

The health professionals involved in the multi professional team of the Psychosocial Attention Center studied 32 professionals. It was decided as an inclusion criterion: professionals with a link to the service for at least one month, this would be the minimum period for involvement with the social and therapeutic insertion activities proposed to the model of care required by the Psychosocial Care Center III. Professionals who did not develop therapeutic activities with the users, on vacation or leave for health treatment were excluded. 
After applying the eligibility criteria, twelve professionals did not meet the inclusion criteria. These were able to participate in the research: two psychiatrists, five nurses, five nursing technicians, two social workers, two psychologists, a pharmacist, a nutritionist, a physical educator and a professional occupational therapist, totaling 20 participants. There was no refusal to participate in the study.

For data collection, two instruments were used. The first one was a questionnaire with closed questions, containing sociodemographic variables (age, sex, marital status, education, profession) and labor (time of work in the service, time of experience in psychiatry, type of labor bond).

The second instrument was a semi structured interview script, which had an average duration of 15 minutes and contained four questions that dealt with comprehension, challenges and potentialities of social inclusion and health promotion activities in the Psychosocial Care Center, namely: What is your understanding about the social inclusion of people with mental disorders in this service? What inclusion promotion activities do you develop here? What challenges did you encounter in these inclusion activities? In what way could promotion of social inclusion be improved? The interviews were recorded on smartphone - offline mode, containing digital recorder application and transcribed in full in Microsoft Office Word $2016^{\circledR}$ software.

In addition to the interview, the non-participatory observational technique, directed to therapeutic activities, was adopted during two weeks (80 hours), with free entry into the venue. The researcher responsible for data collection noted relevant information, observed during the interviews, and therapeutic activities in the service, based on a guideline for observations, in order to analyze the environment, participants, frequency and duration, process and outcome from the questions: who are the participants (professionals)? What are their characteristics and roles? What time did the activity start and at what time did it end? Is it recurring? How is the activity organized and how is it developed? Is the environment adequate for the observed activity? Explain.

The observation occurred through the follow-up of the professionals in the activities carried out with the users inside and outside the Psychosocial Care Center. Observational data from the interview were revealed during discussion of the categories of analysis, with a view to confronting "what was said and done" by participants. Participants were coded, regardless of category, such as Interview 1 and so on (eg. I1 ... I20).

The data preparation, after collection (interview and observation), occurred in two stages. First, the information about the characterization of the research participants was organized, in a descriptive way, with the help of Microsoft Office Excel® 2016 software. Afterwards, the data obtained from the interviews (speeches of the participants) were transformed into a textual corpus for processing in the Analyse Lexicale par Contexte d'un Ensemble de Segments de Texte (ALCESTE) software, form of analysis of computerized content ${ }^{(6)}$.

In the order obtained by ALCESTE, each interview is considered an Initial Context Unit (UCI), a unit from which the program will effect fragmentation. These ICUs correspond to each interview, considering the speech of each participant ${ }^{(6)}$. For the treatment and categorization of the classes generated by ALCESTE, software processing was associated with the Content Analysis stages ${ }^{(7)}$.

The professionals participated voluntarily, after clarifying the objectives and purposes of the research, all of them having signed the Free and Informed Consent Form and the Authorization Term for Voice Recording.

The research complied with the norms of Resolution 466/2012 that guides researches with human beings and obtained approval from the Committee of Ethics in Research with Human Beings of the State University of Rio Grande do Norte, according to opinion no $1,441,884$, Certificate of Presentation for Appreciation Ethics no $53357216,5,0000,5294$. 


\section{Results}

The socio-demographic profile of the professionals showed a predominance of female $(60.0 \%)$, with the majority in the age group 30 - 39 years old $(60.0 \%)$ and the highest percentage of unmarried people (55.0\%). In relation to working time, $45.0 \%$ were 2 to 3 years of age, serving in the Psychosocial Care Center III and had mental health experience of 0.4-4 years $(70.0 \%)$.

The corpus processed by ALCESTE obtained $60.0 \%$ of the material, considered optimal, with 105 Elementary Context Units (ECU) analyzed. Such a categorical system belongs to the discursive set of health professionals interviewed about the theme of social inclusion. Through the Classes pointed out by ALCESTE, by means of the Descending Hierarchical Classification, three categories of analysis were generated, according to the thematic content and interpretation of the ECU present. The classes below and their content are associated with the coefficient $P h i$, which demonstrates strong link between the word and the class by means of the coefficient $>0.20$.

For each category, professionals' speech - ipsis litteris - was used to valorize the symbology and the different meanings that the participants referred to the daily life and it's dialogic with the theme, that is, ways of speaking and interpreting, respecting the recommendations of the preparation of the corpus.

Class 1 obtained retention of $27.0 \%$ of ECU, associated, semantically, with the following forms of words (phi value): principal (0.38); vez (0.31); pass (0.3); familia $(0.32)$; ve $(0.27) ;$ casa $(0.27)$; muita (0.27); dia (0.25); ger (0.22); cheg (0.24); deix (0.24); entr (0.24); sair (0.24); renda (0.24); saude (0.24); carinho (0.24) and ano (0.22). The category Social inclusion: family participation in inclusion/exclusion and income generation, which presents the family institution as nucleus capable of strengthening the social inclusion of people living with mental disorders, evidenced, mainly, by the capacity of self-employment and income generation. In addition, it was also able to structure exclusive processes that impact on the well-being of the family being followed in the Psychosocial Care Center, according to speeches: Another issue also of social inclusion, when we talk about the family, still has this rejection ... already starting inside the house in the house, the family does not accept, when they are in trouble, the family, sometimes, does not let out on the sidewalk, the family itself (I12). For people, it is strengthening and effecting this social inclusion, also promoting more workshops to generate employment and income that they can learn here and take home, work in the family in this workshop, that from this workshop, they will have an extra income (I01).

In relation to the second category (Class 2), with $25.0 \%$ of ECU, it was associated to the words ( $p h i$ value): atividade (0.47); volt (0.34); grupo (0.32); terapia (0.32); particip (0.32); cap (0.28); medica (0.29); desenvolv (0.29); fisic (0.26); sintomas (0.26); familiar (0.24); transtorn (0.24); clin (0.23); forma (0.23); cidade (0.23); enfermage (0.23); interess (0.21). It was named as Therapeutic Activities: inclusion inside and outside the Psychosocial Care Center, it was highlighted in the speech of the professionals to carry out activities inside and outside the Psychosocial Care Center III, as a form of social inclusion, as stimulators of the autonomy and citizenship, due to the years lost due to the incapacity of social and family life, causing onus on the aspects required to live the daily life. The speeches illustrate this process: He is participating in community activities ... daily activities ... go to a pharmacy, go buy bread ... cultural attractions. So it is included in what, in the concept of society ... is interacting with the community (I11). Here at the Psychosocial Care Center, we have the part ... the nursing is very much part of the assistance, then, the administration of the medications, all of this. We participate in a complementary way, the actions of the therapy ... Then there is a show, there is a tour on the island, they have these activities, we ... we ended up contributing to this (I11).

Finally, Class 3 (8.0\% ECU) was associated with the terms ( $p h i$ value): servico (0.49); pesso (0.44); aceit (0.43); sab (0.41); usuario (0.36); important (0.36); vend (0.34); gestao (0.34); profissio (0.30); dificil (0.28); sent (0.25); mundo (0.25); quebr (0.25); tempo (0.25); contato (0.25); cuidado (0.25); envolvime (0.25). It generated the category Challenges of 
Inclusion: service management and professional training, insofar as the implementation of social inclusion in any field is not restricted to the work process and actions of health professionals, management, with planning and assistance to the teams (education in the service), as the participants reported: And it depends a lot on the management issue, sometimes we do a lot of things only of our own volition, but sometimes people need transportation to go somewhere else, to include even in society, and sometimes we do not have (I12). Very important are the professionals who are not well prepared, because, thus, you are dealing with a difficult thing ... So, of all of these, I think the main, the main challenge is the lack of preparation for professionals (I16).

\section{Discussion}

This study aimed to identify the perceptions of the multi professional team of a psychosocial care center on social inclusion. However, there are limitations that refer to the regionality and lack of literature on social inclusion actions in substitutive mental health services. However, the magnitude of the research is acknowledged by offering conditions for re-elaboration of the processes that lead to the strengthening of the psychosocial network and the applicability of strategies that foster Brazilian psychiatric reform.

Regarding the results, the first category "Social inclusion: family participation in inclusion/exclusion and income generation" showed that family participation in decision making, evaluation of the service and professionals working with users have positive effects in the recovery of users, which corroborates with the literature ${ }^{(8)}$. Thus, it is the commitment and responsibility of the technical team to identify ways of including family members during the care process, although the difficulty of this practice in the Psychosocial Care Center investigated has been perceived, especially with regard to family participation in the reintegration of users to society.

For effective and efficient social and family inclusion, the stigmas associated with users should be softened. However, the exclusion of the person with mental disorder has been perpetuating for years, and in many situations, treatment is still done through labeling and maintenance of the user in places that focus on the asylum model making it professional, generating family and social exclusion ${ }^{(3)}$.

Despite the need to intervene in the social environment, in the scenario investigated, it was observed that no systematic and permanent activity was developed with the external population, that is, the community. In this sense, attention should be paid to the development of reflection on work in the community and in social spaces, evaluating and planning the permanent access of users to other spaces, such as museums, libraries, cultural centers, squares.

From the perspective of the community insertion, the professionals reported the importance of income generating work as a form of learning and social inclusion. Another research showed that therapeutic workshops allow the possibility of highlighting internal/external conflicts through artistic activities, valuing the creative, imaginary and expressive potential of the user; which will make him more socially apt $\mathrm{t}^{(9)}$, regardless of whether they are devices capable of learning a trade, or generating income.

It was observed that, in spite of presenting technical capacity, the professionals involved in the workshops conducted these activities not related to the users' needs, since they are not thought according to a therapeutic proposal, individualized. However, it was noticed that the workshops stimulate users to develop creativity and express emotions in diagnostic frameworks through the relation of art, which in other evidences is manifested as a process of (re)construction of subjects' autonomy ${ }^{(10)}$. In the meantime, it is known that these activities potentiate the process of treatment and inclusion, increasing perception and awakening the creativity of individuals ${ }^{(11)}$.

Regarding the second category: Therapeutic Activities: inclusion inside and outside the Psychosocial Care Center, the functions indicated for the subs- 
titutive service make possible a challenging, historical and social process in the promotion of inclusion in the labor market and in the relationships of affection and parenting, preserving singularity, history, culture and daily life, which are necessary to prevent impacts on the social group that may lead to their exclusion ${ }^{(12)}$.

However, it was observed, through non-participant observation, the barrier of nursing professionals to identify their role in the therapeutic activities, identifying themselves as responsible for training and also the bureaucratic work performed, a reality that is in line with the nursing challenges to exercise the reformist role in the Psychosocial Care Center, in which it has presented an authoritarian, restrictive and discriminatory attitudinal profile regarding mental illness ${ }^{(13)}$.

From the Psychiatric Reform, substitute services began to focus on the user according to community and affective, social, family and community relationships ${ }^{(14)}$. However, in the reality of the Psychosocial Care Center investigated, the professionals recognized that the service still had few opportunities to practice the mobility of users in the territory and that it was necessary to work with the community/ population, to propose actions and activities in the community perspective and dimension.

The permanent opportunities of external activities experienced in this service fell short of the real needs of the users. During the observation period, only two professionals of physical education and craftsman produced external activities with the users (sports court and soccer field, walk in the commerce and community areas), without articulation with the other members of the team thus reaffirming that most of the activities were carried out individually, without following the precept of interdisciplinarity ${ }^{(15)}$.

In addition, few internal users in the beds of the Psychosocial Care Center analyzed participated in these external activities, demonstrating total immersion in the asylum model, something close to the internalization of the compulsory hospitalization model and social exclusion, to the detriment of a psychosocial view, as a specific therapeutic attitude to substitute services $^{(3)}$.

Finally, as a third category: Challenges of Inclusion: service management and professional training, this study identified the lack of resources to carry out activities of the service, being common aid and donations from the community to carry out activities or, the sale of handicrafts for the purchase of new materials, in order to maintain the workshops.

Consonant to the reality found, regarding the financing of mental health services and the challenges to the implementation of routines and inclusive activities, it is observed that mental health is a underfunded area in the Unified Health System, a situation that constrains the progress of these essential services and, consequently, precarious psychosocial attention. Contrary to the reform process, it is noted that therapeutic communities have been protagonists in the investment of mental health policies ${ }^{(16)}$.

The professionals interviewed also spoke about the profile perspective, professional preparation to work in the area, understanding them as ways, also, of possible social insertion of users of Psychosocial Care Center, in which prejudice and stigma with insanity are part of the social imaginary while representation and perception of what still seems hidden, magical and proper to the spiritual field.

These processes of misunderstanding in the magic and religious field directly influence the profile and the professional preparation to act in the field of mental health. Thus, the literature has pointed to managers' responsibility for the difficulties identified with the use of permanent health education and the necessary resources to advance the implementation of mental health policies ${ }^{(4)}$.

The problems and difficulties reported are not only part of the local reality, but also of several scenarios with Psychosocial Care Center in Brazilian states. In São Paulo, for example, the evidence points to the continued generalization and barriers in the active participation of several professional actors in the production of permanent education in mental health 
services, as well as valuation in the formatting of activities and bureaucratization of actions ${ }^{(17-18)}$.

In order to face this process, it is necessary to make an effort on the points discussed, especially regarding the processes of permanent education of the professionals and recognition of the managers about the importance of investment in this care sector. Therefore, the need for more intense work in universities and health training schools on mental health is highlighted, as there is still a lack of knowledge about the subject.

\section{Conclusion}

Prejudice or discrimination in this field, coupled with the difficulties of support of management with service and stiffening of the work process with centrality in the psychiatric consultation, harms attempts at rehabilitation and social inclusion of users and families.

\section{Acknowledgements}

To the Coordenação de Aperfeiçoamento de Pessoal de Nível Superior, for the promotion of this research - Code of Financing 001, to the Universidade do Estado do Rio Grande do Norte, for granting the Scientific Initiation Scholarship and the Universidade Federal do Rio Grande do Norte for funding of publication costs.

\section{Collaborations}

Azevedo DM and Bessa MS contributed in designing the project, analyzing and interpreting the data, writing the article and critically reviewing the intellectual content. Silva GWS, Miranda FAN, Lins SLF and Costa JE collaborated with data analysis and interpretation, article writing and critical review of the intellectual content and approval of the final version to be published.

\section{References}

1. Macedo JP, Abreu MM, Fontenele MG, Dimenstein $M$. The regionalization of mental health and new challenges of the psychiatric reform in Brazil. Saúde Soc. 2017; 26(1):16-23. doi: https://doi. org/10.1590/S0104-12902017165827

2. Nóbrega MPSS, Silva GBF, Sena ACR. Psychosocial rehabilitation in the west network of the municipality of São Paulo: potentialities and challenges. Rev Gaúcha Enferm. 2018; 39:e20170231. doi: http://dx.doi.org/10.1590/19831447.2018.2017-0231

3. Amarante P, Nunes MO. Psychiatric reform in the SUS and struggle for a society without asylums. Ciênc Saúde Coletiva. 2018; 23(6):206774. doi: http://dx.doi.org/10.1590/141381232018236.0 7082018

4. Bee P, Brooks H, Fraser C, Lovell K. Professional perspectives on service user and carer involvement in mental health care planning: A qualitative study. Inter J Nurs. 2015; 52(12):1834-45. doi: https:// doi.org/10.1016/j.ijnurstu.2015.07.008

5. Clifton A, Repper J, Banks D, Remnant J. Co-producing social inclusion: the structure/agency conundrum. J Psychiatr Ment Health Nurs [Internet]. 2013 [cited Set. 02, 2018];20(6):514-24. Available from: www.ncbi.nlm.nih.gov/pubmed/22882808

6. Azevedo DM, Costa RKS, Miranda FAN. Use of the alceste in the analysis of qualitative data: contributions to researches in nursing. Rev Enferm UFPE on line [Internet]. 2013 [cited Sept. 02, 2018]; 7(esp):5015-22. Available from: https:// periodicos.ufpe.br/revistas/revistaenfermagem/ article/view/11764/14082

7. Silva AH, Fossá MIT. Análise de conteúdo: exemplo de aplicação da técnica para análise de dados qualitativos. Qualit@s Rev Eletr [Internet]. 2015 [citado 2018 set. 02];17(1):1-14. Disponível em: http://oficinas.incubadora.ufsc.br/index.php/ Lucasfranco/article/view/2336/2155

8. Azevedo DM, Oliveira AM, Melo GSM, Salvetti MG, Vasconcelos QLDAQ, Torres GV. Evaluation of assistance in center of psychosocial care in the perspective of professionals. Rev Bras Pesqui Saúde. 2014 [cited Sept. 02, 2018];16(2):109-16. Available from: http://periodicos.ufes.br/RBPS/ article/view/9293/6467 
9. Costa MGSG, Figueiró RA, Freire FHMA. The phenomenon of Chronification on Psychosocial Aid Centers: a case study. Temas Psicol. 2014; 22(4):839-51. doi: http://dx.doi.org/10.9788/ TP2014.4-13

10. Santos ES, Joca EC, Souza AMA. Teatro do oprimido em saúde mental: participação social com arte. Interface (Botucatu). 2016; 20(58):637-47. doi: http://dx.doi.org/10.1590/1807-57622015.0469

11. Mendes MF, Lopes VB, Lobo APA. Mental health and art: workshop experiences aesthetic report in a psychosocial care center. Cad Bras Saúde Ment [Internet]. 2016 [cited Sept. 02, 2018];8(20):708. Available from: http://incubadora.periodicos. ufsc.br/index.php/cbsm/article/view/3992

12. Ibiapina ARS, Monteiro CFS, Alencar DC, Fernandes MA, Costa Filho AAI. Therapeutic workshops and social changes in people with mental disorders. Esc Anna Nery. 2017; 21(3):e20160375. doi: 10.1590/2177-9465-EAN-2016-0375

13. Gonçalves AM, Vilela SC, Terra FS. Attitudes of professionals of the Network of Psychosocial Attention to mental illness. Rev Rene. 2017; 18(5):64754.doi:http://dx.doi.org/10.15253/21756783.2017000500012
14. Jorge MSB, Vasconcelos MGF, Castro Junior EF, Barreto LA, Rosa LRS, Lima LL. Solvability of mental health care in the Family health strategy: social representation of professionals and users. Rev Esc Enferm USP. 2014; 48(6):1062-8. doi: http://dx. doi.org/10.1590/S0080-623420140000700014

15. Araujo Filho JD, Bessa MS, Azevedo DM. Mental health care in a Counseling and Psychosocial Service: evaluation in the professional perspective. J Nurs Health [Internet]. 2016 [cited Sept. 02, 2018];6(2):279-86. Available from: https://periodicos.ufpel.edu.br/ojs2/index.php/enfermagem/article/view/5779/6044

16. Trapé TL,Campos RO. The mental health care model in Brazil: analyses of the funding, governance processes, and mechanisms of assessment. Rev Saúde Pública. 2017; 51(19). doi: http://dx.doi. org/10.1590/s1518-8787.2017051006059

17. Silva DLS, Knobloch F. A equipe enquanto lugar de formação: a educação permanente em um Centro de Atenção Psicossocial Álcool e outras drogas. Interface (Botucatu). 2016; 20(57):325-35. doi: http://dx.doi. org/10.1590/1807-57622015.0061

18. Medeiros GT, Nascimento FAF, Pavòn RG, Silveira FA. Educação Permanente em Saúde Mental: relato de experiência. Interface. 2016; 20(57):475-84. doi: http://dx.doi.org/10.1590/1807-57622015.0232 